\title{
A Numerical Taxonomic Study of Some Pseudomonas-like Marine Bacteria
}

\author{
By J. V. LEE,* D. M. GIBSON† AND J. M. SHEWAN \\ Ministry of Agriculture, Fisheries and Food, Torry Research Station, Aberdeen AB9 8DG
}

(Received 13 August 1976)

\begin{abstract}
SUMMARY
The abilities of 26 marine and $\mathrm{r} 2$ other Pseudomonas-like strains of bacteria to grow on single carbon sources, their antibiotic sensitivities and complement of some enzymes of intermediary metabolism were numerically analysed and gave five phenons. Two phenons contained strains with more than $55 \mathrm{~mol} \% \mathrm{GC}$ and were regarded as Pseudomonas spp., two were similar to the genus Alteromonas, and one was an intermediate phenon. Tests for identifying such organisms are proposed. Pseudomonas putrefaciens Derby \& Hammer I93I and $P$. rubescens Pivnick 1955 should be considered synonyms of Alteromonas putrefaciens Derby \& Hammer comb. nov.
\end{abstract}

\section{INTRODUCTION}

The identification of Gram-negative rods from aquatic and food sources has proved difficult due to the unsatisfactory state of their taxonomy. The scheme of Shewan, Hobbs \& Hodgkiss (1960) has proved as useful as any other to the applied bacteriologist: it includes the possession of pigmentation, cytochrome oxidase, catalase and the mode of metabolism of glucose in Hugh \& Leifson's (I953) test. Pseudomonas species of their groups I and II correspond to those of the genus Pseudomonas as defined by Palleroni \& Doudoroff (1972). The organisms in groups III and IV include such named strains as $P$. atlantica, $P$. putrefaciens, $P$. rubescens and $P$. testosteroni, all of which are of considerable economic importance. Indeed, Shewan (1974) regards $P$. putrefaciens as one of the most important organisms encountered in the spoilage of protein foods kept at chill temperatures $\left(2\right.$ to $\left.4{ }^{\circ} \mathrm{C}\right)$. Many isolates from the sea (Herbert et al., 1971), from cutting oils (Pivnick, 1955) and from clinical material (Levin, 1972; Riley, Tatum \& Weaver, 1972) are similar to it. The mol \% GC of the DNA of many organisms of groups III and IV is much lower (40 to $55 \%$ ) than that of the genus Pseudomonas ( 58 to $70 \%$; Palleroni \& Doudoroff, 1972). However, in routine bacteriological tests they are indistinguishable from other group III and IV strains whose mol \% GC fit the genus. It seemed, therefore, appropriate that a more detailed study of the groups III and IV pseudomonads be undertaken especially to distinguish the low mol \% GC strains from the true Pseudomonas.

While the work described here was in progress, Baumann et al. (1972) reported on the taxonomy of 218 strains of Gram-negative, non-fermentative, marine bacteria. All the polarly flagellated organisms required $\mathrm{Na}^{+}$for growth and had 30.5 to $64.7 \mathrm{~mol} \% \mathrm{GC}$. Those with mol \% GC above 57.8 were placed in the genus $P$ seudomonas; those with mol \% GC between 43.2 and 48 were placed in a new genus Alteromonas, which was distinct from the former solely on the grounds of DNA base composition, despite extensive characteriza-

\footnotetext{
* Present address: Public Health Laboratory, Preston Hall Hospital, Maidstone, Kent ME2O 7 NH.
} $\uparrow$ To whom reprint requests should be addressed. 
tion. The rest of the strains were unassigned. These workers emphasized the limitations of their results due to the very restricted ecology of their isolates. The genus Alteromonas as described includes organisms that would be placed in groups III and IV of Shewan et al. (1960). It is therefore necessary to compare any groups of low mol \% GC described here with Alteromonas species.

Since the groups III and IV strains gave negative results in most routine bacteriological tests, they were subjected to a nutritional screening and some rapid biochemical tests (Kersters, 1967). This paper describes a numerical taxonomic analysis of these organisms based on the results obtained. A preliminary report has been presented (Lee, Gibson \& Shewan, 1973).

\section{METHODS}

Bacterial strains and their culture. Their designation and sources are shown in Table I. Those requiring sea water for optimum growth were grown routinely in Leifson's (I970) medium $\mathbf{M}$ which contained (g per 1 distilled water): Bacto-casitone (Difco), 2; Bacto-yeast extract (Difco), I; $\mathrm{NaCl}, 20 ; \mathrm{KCl}, \mathrm{I} ; \mathrm{MgCl}_{2} \cdot 6 \mathrm{H}_{2} \mathrm{O}, 4 ; \mathrm{CaCl}_{2} \cdot 2 \mathrm{H}_{2} \mathrm{O}$, I ; and Tris, 0.5. The Tris was added as a solution adjusted with $\mathrm{HCl}$ to $\mathrm{pH} 7 \cdot 5$ to $8 \cdot 0$ and the medium was solidified, if required, with agar ( $5 \mathrm{~g} \mathrm{l}^{-1}$ ). Medium $\mathrm{L}$, containing $5 \mathrm{~g} \mathrm{NaCl}^{-1}$ but otherwise the same as medium $\mathrm{M}$, was used for the cultivation of other strains. All cultures and growth tests were incubated at $20^{\circ} \mathrm{C}$.

Buffers. Phosphate buffers were prepared from $0.2 \mathrm{M}$ stock solutions of $\mathrm{Na}_{2} \mathrm{HPO}_{4}$ and $\mathrm{KH}_{2} \mathrm{PO}_{4}$, and Tris/ $\mathrm{HCl}$ buffers were prepared from $0.4 \mathrm{M}$ stock solutions of Tris and $\mathrm{HCl}$. For marine strains, phosphate plus marine salts buffer was used. The salts $(\mathrm{NaCl}, 17.5 \mathrm{~g}$; $\mathrm{KCl}, \mathrm{I} \cdot 0 \mathrm{~g}$; and $\mathrm{MgCl}_{2} \cdot 6 \mathrm{H}_{2} \mathrm{O}, \mathrm{I} \cdot 6 \mathrm{~g}$ ) were dissolved in $850 \mathrm{ml}$ distilled water, the phosphate solutions were mixed (to give $0.0 \mathrm{r} \mathrm{M}$ ) and added to the salts solution and the volume was adjusted to I 1 . The buffers were not sterilized.

Requirement for $\mathrm{Na}^{+}$for growth. Strains were tested for their ability to grow in basal medium, basal medium plus $2.9 \mathrm{~g} \mathrm{NaCl}^{-1}$ and basal medium plus $17.5 \mathrm{~g} \mathrm{NaCl}^{-1}$. The basal medium contained (g per 1 deionized distilled water): $\mathrm{KCl}, 0.5 ; \mathrm{MgCl}_{2} \cdot 6 \mathrm{H}_{2} \mathrm{O}, 2 \cdot 0$; $\mathrm{CaCl}_{2} .2 \mathrm{H}_{2} \mathrm{O}, 0.5 ;$ Tris, $6 \cdot 0 ; \mathrm{H}_{3} \mathrm{PO}_{4}, 0.032 ; \mathrm{FeCl}_{3} .6 \mathrm{H}_{2} \mathrm{O}, 0.008$; glucose, $\mathrm{I} \cdot 0$; and $0.25 \mathrm{~g}$ each of L-methionine, L-alanine, L-valine, L-asparagine, L-proline, and L-threonine. The Tris was added as a solution adjusted to $\mathrm{pH} 7.5$ with $\mathrm{HCl}$. Tubes $(\mathrm{I} 50 \times 16 \mathrm{~mm})$ containing $5 \mathrm{ml}$ medium sterilized at $\mathrm{I2} \mathrm{I}{ }^{\circ} \mathrm{C}$ for $15 \mathrm{~min}$ were inoculated in duplicate, using a straight wire, from 2-day-old plate cultures of medium $\mathrm{M}$ or $\mathrm{L}$. The ability of a strain to show visible growth on one or both $\mathrm{Na}^{+}$-containing media but not on the basal medium within ro days indicated a requirement for $\mathrm{Na}^{+}$for growth.

Effect of $\mathrm{Na}^{+}$concentration on growth. Twenty four $\mathrm{Na}^{+}$-requiring strains were grown in triplicate in Leifson's liquid medium $M$, modified to contain $0.005,0.05,0.10,0.20,0.30$, $0.40,0.50,0.75$ and $\mathrm{r} .33 \mathrm{M}-\mathrm{NaCl}$, dispensed in $5 \mathrm{ml}$ amounts in $150 \times 16 \mathrm{~mm}$ tubes. Tubes were inoculated with one drop of $24 \mathrm{~h}$ broth culture. After $24 \mathrm{~h}$ incubation, growth was stopped by the addition of $0.2 \mathrm{ml} 36 \%$ formaldehyde and determined by measuring $E_{580}^{1 \mathrm{~cm}}$ in a Pye Unicam SP600 spectrophotometer.

Antibiotic sensitivities. The sensitivities of the strains were determined using Multodisks (Oxoid) applied to flood inoculated dried plates of medium $\mathbf{M}$ for the marine strains, or Oxoid $\mathrm{CM}_{3}$ for the others.

Deoxyribonuclease. DNAase was detected by the method of Jeffries, Holtman \& Guse (I957) using Bacto-DNAase Test Agar (Difco) supplemented for marine strains with $2 \%$ (w/v) $\mathrm{NaCl}$. 
Table I. Strains used and their sources

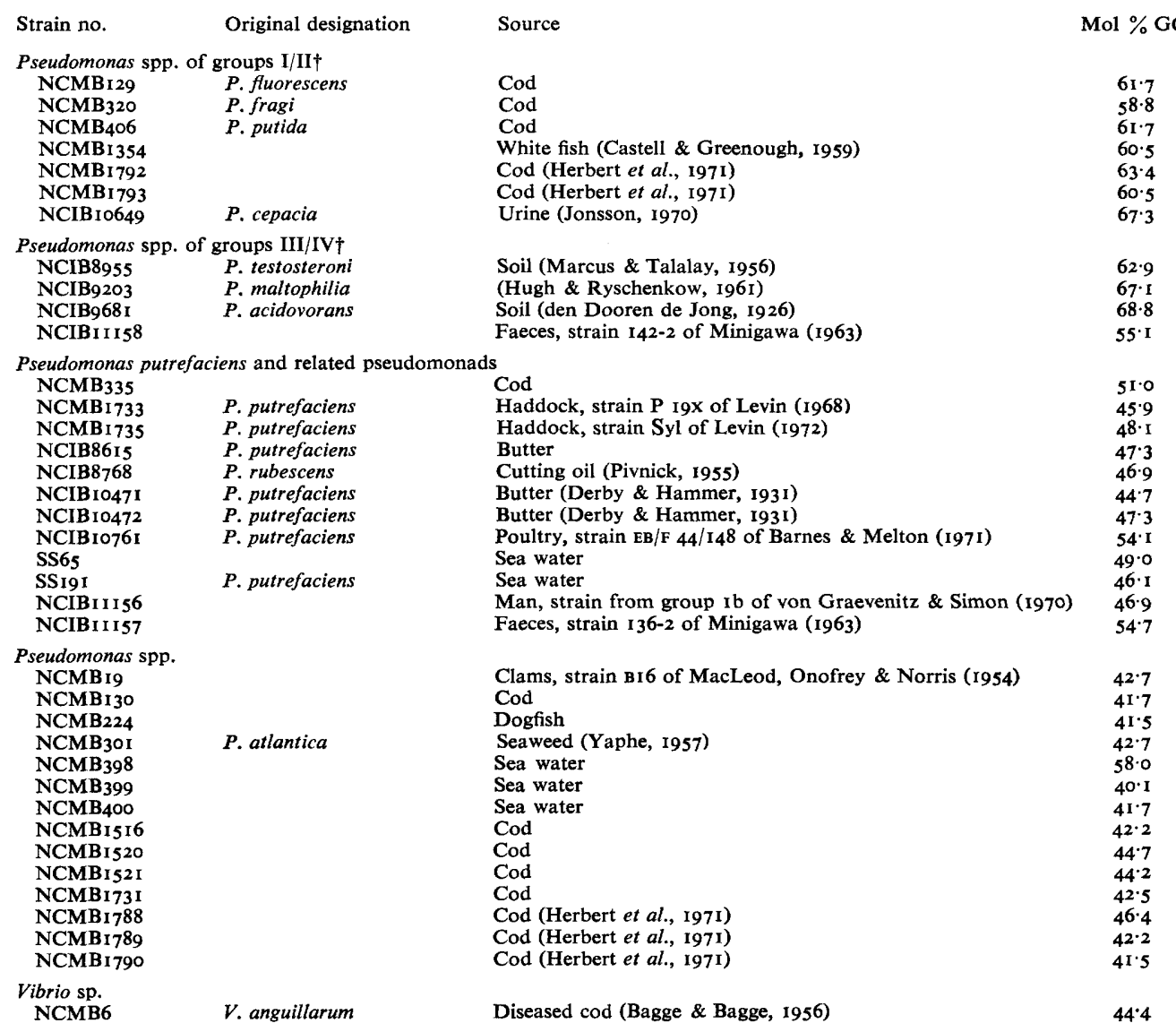

NCMB, National Collection of Marine Bacteria; NCIB, National Collection of Industrial Bacteria, both of Torry Research Station; SS, Statens Seruminstitut, Copenhagen, Denmark.

* Mol \% GC determined by Gibson \& MacLeod (unpublished results).

$\dagger$ Groups I/II and III/IV refer to the pseudomonad groups of Shewan et al. (1960).

Reduction of trimethylamine oxide. The ability of the strains to reduce trimethylamine oxide (TMAO) to trimethylamine was determined according to the method of Laycock \& Regier (197I) except that $20 \% \mathrm{KOH}$ was used instead of $\mathrm{K}_{2} \mathrm{CO}_{3}$ (Murray \& Gibson, 1972). Hydrogen sulphide production. The ability to produce $\mathrm{H}_{2} \mathrm{~S}$ from L-cystine was tested on Bacto-Motility Sulphide Medium (Difco) supplemented for marine strains with $2 \% \mathrm{NaCl}$.

Decarboxylases. Lysine and ornithine decarboxylases were detected by the method of Møller (1955).

Arginine dihydrolase. Arginine dihydrolase was detected by the method of Thornley (1960). Nutritional screening. The strains were tested in triplicate for their ability to grow on 72 compounds at $0.1 \%(\mathrm{w} / \mathrm{v})$ final concentration as the sole source of carbon, with ammonia and nitrate as nitrogen source. The basal medium for the marine strains contained the following salts (g): $\mathrm{NaCl}, 20 ; \mathrm{KCl}, \mathrm{I} ; \mathrm{MgCl}_{2} \cdot 6 \mathrm{H}_{2} \mathrm{O}, 4 ; \mathrm{CaCl}_{2} \cdot 2 \mathrm{H}_{2} \mathrm{O}$, I; $\left(\mathrm{NH}_{4}\right)_{2} \mathrm{SO}_{4}$, I ; $\mathrm{NH}_{4} \mathrm{NO}_{3}, \mathrm{I}$; and $\mathrm{FeCl}_{3} .6 \mathrm{H}_{2} \mathrm{O}, 0.008$. Distilled water $(250 \mathrm{ml})$ and $0.2 \mathrm{M}$-Tris buffer (pH 6.5; $250 \mathrm{ml}$ ) containing $330 \mu \mathrm{mol} \mathrm{H}_{3} \mathrm{PO}_{4}$ were added and the mixture was autoclaved at I2I ${ }^{\circ} \mathrm{C}$ 
for $20 \mathrm{~min}$ before adding sterile distilled water or sterile $2 \%(\mathrm{w} / \mathrm{v})$ purified agar (Oxoid) $(500 \mathrm{ml})$. The basal medium for the other strains was the liquid minimal medium or minimal agar of Clowes \& Hayes (1968). If sufficiently soluble, the carbon sources were prepared as concentrated solutions which were sterilized by membrane filtration; otherwise they were dissolved in the minimal medium and autoclaved at 1 I $5{ }^{\circ} \mathrm{C}$ for Io min.

The media were dispensed in 25 compartment Replidishes (Sterilin, Richmond, Surrey) to avoid the possibility of the strains cross-feeding, and inoculation was by means of a simple replicating device (Lee, I973). Positive growth was recorded for any strain which, after I4 days incubation, showed more growth on the particular substrate than on the control medium.

Pseudomonas maltophilia NCIB9203 requires methionine for growth; it was examined separately in methionine ( $0.1 \%$ ) supplemented media. Pseudomonas atlantica NCMB30I can grow on agar as the sole source of carbon and was therefore tested in liquid media.

Cell-free extracts. Strains were grown in either medium M or L supplemented with $0.1 \%$ $(\mathrm{w} / \mathrm{v})$ sodium gluconate and $0 . \mathrm{I} \%(\mathrm{w} / \mathrm{v})$ glucose in four 21 conical flasks each containing $500 \mathrm{ml}$ medium. Each flask was inoculated with $\mathrm{I} \mathrm{ml}$ of an overnight starter broth culture and incubated at $20^{\circ} \mathrm{C}$ in a cooled orbital incubator (model IH-465, Gallenkamp) at 250 rev. $\min ^{-1}$. Bacteria were harvested in the late-exponential phase of growth $\left(E_{580}^{1 \mathrm{~cm}}\right.$ approximately $\mathrm{I} \cdot 5)$ by centrifuging at $8000 \mathrm{~g}$ for Io min at $20^{\circ} \mathrm{C}$ and washed twice in 0.01 M-phosphate buffer, $\mathrm{pH} 77^{\circ}$. About Io g packed wet wt cells were suspended in $15 \mathrm{ml} 0 \cdot 0 \mathrm{I}$ M-phosphate buffer, $\mathrm{pH} 7 \cdot 0$, and added to a $50 \mathrm{ml}$ MSK bottle (Braun, Melsungen, Germany) containing $50 \mathrm{~g}$ glass beads ( $0 \cdot 10$ to $0 \cdot 1 \mathrm{I} \mathrm{mm}$ diam.) all at $4{ }^{\circ} \mathrm{C}$. The cells were broken by shaking for $3 \mathrm{~min}$ at $4000 \mathrm{rev}$. $\mathrm{min}^{-1}$ in a cooled Braun Disintegrator. The mixture was fractionated into a soluble enzyme and a particulate fraction according to the scheme of Kersters (1967).

No extracts could be prepared from NCMB335 because it was not possible to grow sufficient organisms.

Enzyme assays. The method of Kersters \& De Ley (1968) was used to assay 6-phosphogluconate dehydrase and 2-keto-3-deoxy-6-phosphogluconate aldolase, and the method of Sols \& Salas (1966) for phosphofructokinase. The NAD- and NADP-linked dehydrogenase activities were determined on the soluble cell fractions and the 2,6-dichlorophenolindophenol-linked dehydrogenases on the particulate fractions by the method of Kersters (1967). The substrates used are listed in Tables 4 and 5. Any change compared with a control without substrate after $\mathrm{I} h$ incubation at $20^{\circ} \mathrm{C}$ was regarded as positive.

Numerical analysis of results. The results from all the above tests except the effect of $\mathrm{Na}^{+}$ on growth, $\mathrm{H}_{2} \mathrm{~S}$ production, decarboxylases and arginine dihydrolase were used in a computer-assisted numerical taxonomic analysis. All results were regarded as two-state characters. Soluble NAD- and NADP-linked and particle-linked dehydrogenases were counted as three separate characters. Since several strains had many negative characters, the coefficient $S_{\mathrm{J}}$ of Jaccard was used to calculate similarities (Sokal \& Sneath, I963). Analyses were performed on the enzyme assay data alone ( 88 characters/strain), on the combined physiological and nutritional data ( 77 characters/strain) and on all the data combined ( 165 characters/ strain). Dendrograms were constructed by complete linkage analysis (Sørensen, 1948) from the similarity matrices which were scanned at decrements of $0.0 \mathrm{I} S_{\mathrm{J}}$.

\section{RESULTS AND DISCUSSION}

The results from enzyme screening assays on subcellular fractions have not previously been used in numerical taxonomic analyses. We therefore computed these data separately 
Table 2. Comparison of phenons derived from enzyme, physiological and nutritional, and combined data using the similarity coefficient $S_{\mathrm{J}}$ and clustering by complete linkage

\begin{tabular}{|c|c|c|c|c|}
\hline \multirow[b]{2}{*}{ Phenon } & \multirow{2}{*}{ Strains always present } & \multicolumn{3}{|c|}{$\begin{array}{l}\text { Level of clustering }(\%) \text { and } \\
\text { additional strains present }\end{array}$} \\
\hline & & $\mathrm{I}^{*}$ & $2^{*}$ & $3^{*}$ \\
\hline A & $\begin{array}{l}\text { NCIBIO649 NCMBI } 792 \\
\text { NCMBI } 793 \text { NCMB406 } \\
\text { NCMBI } 354 \text { NCMBI } 29 \\
\text { NCMB320 }\end{array}$ & $52 \%$ & $56 \%$ & $54 \%$ \\
\hline B & $\begin{array}{l}\text { NCIB I I I } 58 \\
\text { NCIB968I } \\
\text { NCIB } 8955\end{array}$ & $31 \%$ & $\begin{array}{c}46 \% \\
\text { NCMB398 }\end{array}$ & $\begin{array}{l}37 \% \\
\text { ss } 65 \dagger \\
\text { NCIB9203 } \\
\text { NCMB398 }\end{array}$ \\
\hline $\mathrm{C}$ & $\begin{array}{ll}\text { NCMB30I } & \text { NCMB I 5I } 6 \\
\text { NCMBI } 789 & \text { NCMB22 } 4 \\
\text { NCMBI } 788 & \text { NCMBI 9 } \\
\text { NCMB399 } & \text { NCMB I 73I }\end{array}$ & $\begin{array}{c}46 \% \\
\text { NCIB8768 } \\
\text { NCMBI } 30\end{array}$ & $43 \%$ & $49 \%$ \\
\hline D & $\begin{array}{l}\text { NCMB I } 520 \\
\text { NCMB400 }\end{array}$ & $47 \%$ & $\begin{array}{c}58 \% \\
\text { NCMBI } 521\end{array}$ & $\begin{array}{c}50 \% \\
\text { NCMB1 } 521\end{array}$ \\
\hline $\mathrm{E}$ & $\begin{array}{l}\text { NCIBI I I } 56 \text { NCMBI } 735 \\
\text { NCIBI I I } 57 \text { SSI9I } \\
\text { NCIB86 I } 5 \text { NCMBI } 733 \\
\text { NCIBI } 47 \text { I }\end{array}$ & $\begin{array}{c}50 \% \\
\text { NCIBIO } 472 \\
\text { NCMBI } 521\end{array}$ & $\begin{array}{l}\quad 41 \% \\
\text { ss65 } \\
\text { NCIBIO } 761 \\
\text { NCIB8768 } \\
\text { NCMB335 }\end{array}$ & $\begin{array}{l}50 \% \\
\text { NCIBIO } 076 \text { I } \\
\text { NCIB8768 } \\
\text { NCIBIO472 }\end{array}$ \\
\hline
\end{tabular}

* I, Data on enzyme analysis of subcellular fractions; 2, nutritional and physiological data; 3, all data combined. The phenons from analysis 3 were those finally accepted.

$\dagger$ Considered to be a member of phenon $\mathrm{E}$ as it has an overall mean similarity $S_{J}$ of $60 \%$ with strains of phenon $\mathrm{E}$ and only $45 \%$ with phenon B strains.

Strains NCMBI 790, I 30 and 6, together with NCMB335 for which there was no enzyme data (see Methods), were not finally allocated to any phenon.

from the combined physiological and nutritional data, as well as combined with them. The three analyses yielded very similar phenons (Table 2), showing that the enzyme screening assays are suitable for taxonomic analysis and suggesting that the phenons are distinct and formed on the basis of a wide range of characters. The phenons derived from the analysis of the combined data (Table 2, Fig. I) are those referred to in the following discussion.

Table 3 summarizes the results of the nutritional and physiological tests useful in separating the phenons. There is a marked correlation between the mol \% GC of the strains and their clustering in the numerical analysis. Thus phenons A and B contain only strains of more than $55 \mathrm{~mol} \% \mathrm{GC}$ and include all the named Pseudomonas species of Palleroni \& Doudoroff (I972) used in this study. Phenons C, D and E contain only strains with less than $55 \mathrm{~mol} \% \mathrm{GC}$.

Many strains required $\mathrm{Na}^{+}$for growth (Table 3) but the response of the strains in the different phenons to increasing concentrations of $\mathrm{Na}^{+}$varied (Fig. 2). No strain grew on methionine, butan-I-ol, o-hydroxybenzoate, formate, malate or on any of the amines. Pseudomonas putrefaciens NCIBI0472 did not grow on any compound as the sole source of carbon but did not have a vitamin requirement as it grew on vitamin-free Casamino acids. The other strains which used few carbon sources were those not clearly belonging to any phenon.

The dehydrogenase activities that correlate with the phenons are shown in Tables 4 and 5 . Activities on sugar phosphates were generally present and not helpful in separating the 


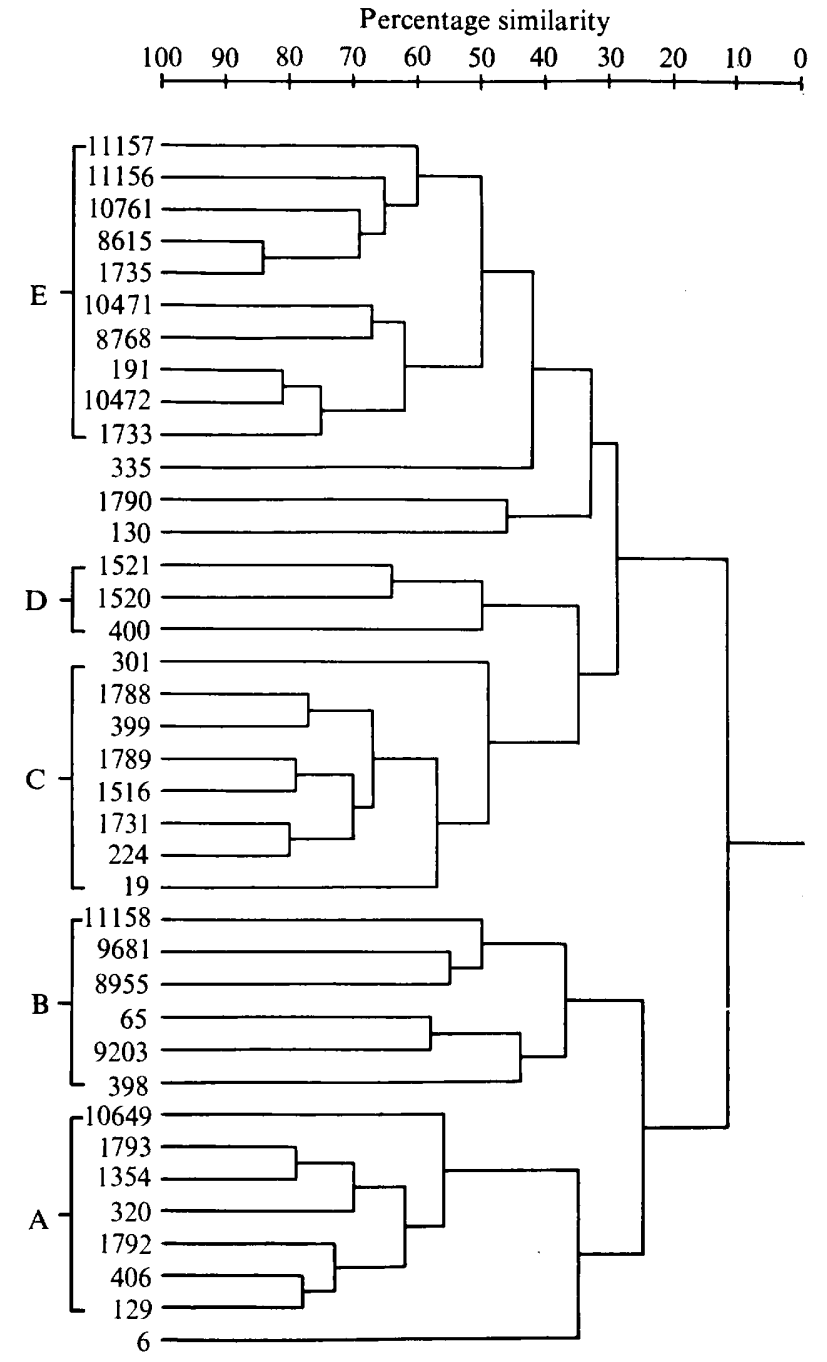

Fig. I. Dendrogram constructed from a complete linkage analysis of the similarities $\left(S_{\mathrm{J}}\right)$ calculated from all the data.

phenons. L-Serine was the only substrate tested that did not stimulate dehydrogenase activity in any strain.

Most strains possessed the enzymes characteristic of the Entner-Doudoroff pathway, 6-phosphogluconate dehydrase and 2-keto-3-deoxy-6-phosphogluconate aldolase. Strains NCMB400 and NCMBI790 had only the latter enzyme, perhaps indicative of the modified pathway described by De Ley et al. (1970). Neither enzyme could be detected in extracts from NCIBI I 58 nor in Vibrio anguillarum, NCMB6, the only strain with phosphofructokinase activity. Extracts from most strains could dehydrogenate 6-phosphogluconate and glucose 6-phosphate, perhaps indicative of the pentose phosphate pathway. Most strains could grow on glucose as the sole source of carbon (Table 3). Thus, although many strains did not produce visible signs (acid or gas) of the metabolism of glucose in Hugh \& Leifson's (I953) test, they could metabolize glucose. 
Table 3. Some differences between phenons in physiological and nutritional attributes

\begin{tabular}{|c|c|c|c|c|c|}
\hline & & & Phenon & & \\
\hline & A & B & $\mathrm{C}$ & $\mathrm{D}$ & $\mathrm{E}$ \\
\hline No. of strains in phenon & 7 & 5 & 8 & 3 & II \\
\hline Mean mol \% GC & $62 \cdot 0$ & $62 \cdot 4$ & $42 \cdot 5$ & $43 \cdot 5$ & $48 \cdot 3$ \\
\hline Range & $58 \cdot 8-67 \cdot 3$ & $55 \cdot I-68 \cdot 8$ & $40 \cdot I-46 \cdot 4$ & $41 \cdot 7-44 \cdot 7$ & $44 \cdot 7-54 \cdot 7$ \\
\hline $\begin{array}{l}\text { Mean no. of single carbon } \\
\text { sources utilized }\end{array}$ & 44 & 24 & 25 & 13 & I9 \\
\hline Requirement for $\mathrm{Na}^{+}$ & - & I & + & + & 2 \\
\hline DNAase & - & I & + & + & + \\
\hline Reduction of TMAO & - & - & - & + & + \\
\hline Production of $\mathrm{H}_{2} \mathrm{~S}$ & I & 2 & - & + & + \\
\hline Inhibition by: & & & & & \\
\hline Tetracycline (Io $\mu \mathrm{g}$ ) & 6 & 4 & - & - & + \\
\hline Erythromycin $(50 \mu \mathrm{g})$ & 3 & + & + & + & + \\
\hline Oleandomycin $(10 \mu \mathrm{g})$ & - & 2 & + & + & 10 \\
\hline Chloramphenicol (10 $\mu \mathrm{g})$ & - & + & + & + & + \\
\hline Furazolidone $(50 \mu \mathrm{g})$ & - & 3 & 7 & + & + \\
\hline Neomycin (Io $\mu \mathrm{g})$ & 6 & 4 & 2 & + & + \\
\hline Nitrofurantoin $(5 \circ \mu \mathrm{g})$ & - & 3 & 3 & + & + \\
\hline Novobiocin $(30 \mu \mathrm{g})$ & I & 4 & 1 & I & I \\
\hline Penicillin ( $\mathrm{I} .5$ i.u.) & - & I & - & + & - \\
\hline Polymyxin B ( 300 i.u.) & 6 & + & + & + & + \\
\hline Streptomycin $(25 \mu \mathrm{g})$ & 6 & 4 & 7 & 2 & + \\
\hline Growth on: & & & & & \\
\hline Glycine & 2 & - & 7 & - & - \\
\hline Isoleucine & 6 & 3 & I & - & 9 \\
\hline Threonine & I & I & 3 & - & 8 \\
\hline Aspartate & + & 4 & 5 & - & - \\
\hline Arginine & + & I & 7 & 2 & - \\
\hline Proline & + & + & + & 2 & - \\
\hline Succinate & + & + & 7 & - & + \\
\hline Malate & + & + & I & + & 7 \\
\hline Glycerol & + & I & - & - & - \\
\hline Glucose & + & 2 & + & + & 8 \\
\hline Ribose & + & I & - & + & 2 \\
\hline Galactose & 6 & I & + & - & I \\
\hline$N$-Acetylglucosamine & 3 & I & 2 & I & 7 \\
\hline Glucosamine & + & I & - & - & 8 \\
\hline Benzoate & 3 & 2 & - & - & - \\
\hline$p$-Hydroxybenzoate & 6 & 2 & - & - & - \\
\hline$m$-Hydroxybenzoate & 3 & 2 & - & - & - \\
\hline Malonate & 4 & 2 & - & - & - \\
\hline Itaconate & 4 & I & - & - & - \\
\hline Protocatechuate & 7 & I & - & - & - \\
\hline $\begin{array}{l}\text { +, Property present in all } \\
\text {-, property absent in all st } \\
\text { The following substrates } \\
\text { asparagine, cysteine, cystin } \\
\text { serine, tryptophan, tyrosine } \\
\text { caproate, citrate, formate, } \\
\text { lactate, maleate, oxalate, p } \\
\text { conate, D-glucuronate, DL } \\
\text { D-trehalose, D-xylose, methy } \\
\text { ethylamine. HCl, diethylami }\end{array}$ & $\begin{array}{l}\text { trains; num } \\
\text { ains. } \\
\text { were also u } \\
\text { glutamate } \\
\text { valine (all } \\
\text { marate, gly } \\
\text { opionate, } p \\
\text { glyceraldeh } \\
\text { lamine. HC }\end{array}$ & $\begin{array}{l}\text { ( } n \text { ) indicate } \\
\text { but were of } \\
\text { tamine, his } \\
\text { lo acids wer } \\
\text { te, glyoxyla } \\
\text { ate, DL-tar } \\
\text { D-mannito } \\
\text { methylamine } \\
\text { hylamine. H }\end{array}$ & $\begin{array}{l}\text { roperty wa } \\
\text { er value in } \\
\text { e, leucine, } \\
\text { the } L \text { form } \\
\text {-hydroxybe } \\
\text { D-arabino } \\
\text { mannose, } \\
\text { l, trimethyl }\end{array}$ & $\begin{array}{l}\text { sent in } n \text { stra } \\
\text { arating the } \\
\text { e, methioni } \\
\text { opan-1-ol, b } \\
\text { te, DL- } \beta \text {-hyc } \\
\text {-arabinose, } \\
\text { amnose, D- } \\
\text { he. HCl, trim }\end{array}$ & $\begin{array}{l}\text { f the pheno } \\
\text { lons: alani } \\
\text { henylalani } \\
\text {-I -ol, aceta } \\
\text { ybutyrate, D } \\
\text { uctose, D-g } \\
\text { itol, sucro } \\
\text { lamine oxi }\end{array}$ \\
\hline
\end{tabular}


Table 4. Presence of soluble NAD- and NADP-linked dehydrogenases in cell extracts

\begin{tabular}{|c|c|c|c|c|c|c|c|c|c|c|}
\hline \multirow[b]{3}{*}{ Substrate } & \multicolumn{10}{|c|}{ Phenon } \\
\hline & \multicolumn{2}{|c|}{$A(7)^{*}$} & \multicolumn{2}{|c|}{ B (5) } & \multicolumn{2}{|c|}{$\mathrm{C}(8)$} & \multicolumn{2}{|c|}{ D (3) } & \multicolumn{2}{|c|}{$E(I I)$} \\
\hline & NAD & NADP & NAD & NADP & NAD & NADP & NAD & NADP & NAD & NADP \\
\hline Alanine & - & - & - & - & 3 & 3 & I & I & - & - \\
\hline Valine & - & - & I & - & + & + & + & + & 10 & IO \\
\hline Threonine & I & I & - & - & + & + & + & + & 9 & 7 \\
\hline Glutamate & - & 5 & I & 3 & - & - & 2 & I & 7 & 5 \\
\hline Acetate & - & - & - & - & 5 & 3 & I & I & 2 & I \\
\hline Succinate & - & - & I & - & I & - & 2 & - & 1 & - \\
\hline Malate & 6 & 6 & 3 & 3 & 2 & + & + & + & + & + \\
\hline Citrate & 2 & I & 3 & + & 7 & 7 & + & 2 & 7 & 6 \\
\hline Isocitrate & + & + & + & + & + & + & + & + & I0 & + \\
\hline Glycerol & - & - & I & - & - & - & I & - & 6 & $I$ \\
\hline
\end{tabular}

+ , Present in all strains; $n$, present in $n$ strains; - , absent in all strains.

* Numbers in parentheses indicate number of strains in phenon.

The following substrates were also examined but were of lesser value in separating the phenons: glycine, serine, lysine, arginine, proline, glycollate, D-lactate, L-lactate, glyoxylate, pyruvate, D-arabinose, L-arabinose ribose, xylose, D-fucose, L-fucose, rhamnose, fructose, galactonate, galactose, gluconate, glucose, mannitol, mannose, sorbitol, sorbose, maltose, sucrose, fructose 6-phosphate, glucose 6-phosphate, 6-phosphogluconate, galactose 6-phosphate, and ribose 5-phosphate.

Table 5. Particle-bound 2,6-dichlorophenolindophenol-linked dehydrogenases

\begin{tabular}{|c|c|c|c|c|c|}
\hline \multirow[b]{2}{*}{ Substrate } & \multicolumn{5}{|c|}{ Phenon } \\
\hline & $\mathrm{A}(7)^{*}$ & B (5) & $C(8)$ & $\mathrm{D}(3)$ & $E(I I)$ \\
\hline Glutamate & 4 & 4 & 6 & I & I \\
\hline Glycollate & - & 2 & - & 2 & I \\
\hline D-Lactate & 5 & 4 & - & 2 & 6 \\
\hline L-Lactate & - & 4 & - & - & 2 \\
\hline Glyoxylate & 2 & I & - & I & I \\
\hline Succinate & I & 3 & + & + & 10 \\
\hline L-Malate & 6 & 3 & - & - & I \\
\hline Citrate & - & - & - & 2 & I \\
\hline Isocitrate & - & - & - & 2 & - \\
\hline L-Arabinose & + & - & - & - & - \\
\hline Xylose & + & - & - & - & - \\
\hline D-Fucose & 6 & - & - & - & - \\
\hline Galactonate & 6 & - & - & - & - \\
\hline Galactose & + & - & - & - & - \\
\hline Gluconate & + & - & - & - & - \\
\hline Glucose & + & - & - & - & - \\
\hline Mannose & + & - & - & - & - \\
\hline Maltose & + & - & - & - & - \\
\hline
\end{tabular}

+ , Present in all strains; $n$, present in $n$ strains; - , absent in all strains.

* Numbers in parentheses indicate number of strains in phenon.

The following substrates were also used but were of lesser value in separating the phenons: alanine, glycine, valine, serine, threonine, lysine, arginine, proline, acetate, pyruvate, glycerol, D-arabinose, ribose, L-fucose, rhamnose, fructose, mannitol, sorbitol, sorbose, sucrose, fructose 6-phosphate, glucose 6-phosphate and 6-phosphogluconate. 


\section{Taxonomic considerations}

Phenon A. This phenon of fairly closely related strains corresponds to the genus Pseudomonas, in particular to groups I and II of Shewan et al. (I960), and includes the species $P$. fluorescens, $P$. fragi, $P$. putida, and $P$. cepacia (NCMBI 29, 320, 406 and NCIBI 0649 respectively). As would be expected from the results of Stanier, Palleroni \& Doudoroff (I966), they were nutritionally the most versatile and $P$. cepacia NCIBro649 could grow on more compounds as sole sources of carbon than any other strain.

Phenon $B$ (excluding ss65). This is the phenon of lowest internal similarity and is analogous to the Pseudomonas groups III and IV of Shewan et al. (1960). It includes three type strains, $P$. testosteroni, $P$. maltophilia, and $P$. acidovorans (NCIB8955, NCIB9203 and NCIB968I respectively).

Strain NCMB398 was the only strain in the phenon requiring $\mathrm{Na}^{+}$for growth. It has $58 \mathrm{~mol}$ $\%$ GC, within the range reported for the genus Pseudomonas (Palleroni \& Doudoroff, 1972), and had similar characteristics to the three $\mathrm{Na}^{+}$-requiring species $P$. doudoroffi, $P$. marina and $P$. nautica described by Baumann et al. (1972). It is most similar to $P$. nautica but differs from it in its ability to grow on valine, glucose, fructose, gluconate and glycerol. It seems inadvisable therefore to assign $\mathrm{NCMB} 398$ to an existing species but the strain is considered to be a member of the genus Pseudomonas.

Strain NCIBI I I 58 has $55 \mathrm{~mol} \% \mathrm{GC}$ which is just below the range suggested for the genus Pseudomonas. Unlike the pseudomonads of phenons A and B, this strain lacked the enzymes of the Entner-Doudoroff pathway and had such a high background fluorescence with NAD that it was impossible to detect NAD-linked dehydrogenase activities. Strains NCIBIO76I and NCIBI I 57 had similar mol \% GC but were placed in phenon E and a third, NCMB335, did not clearly belong to any phenon but was most closely related to strains of phenon $\mathrm{E}$. Strain NCIBII 158 had relatively high similarity to these three strains and to some other strains of phenon E. Thus, although nearer to phenon B than E, NCIB I I I 58 is an intermediate and may represent those strains of intermediate mol \% GC that Baumann et al. (1972) did not assign to a genus.

Phenon $C$. This phenon contains quite closely related strains, requiring $\mathrm{Na}^{+}$for growth with an optimum at about $0.3 \mathrm{M}$ (Fig. $2 c$ ). They were nutritionally the most versatile of the low mol \% GC organisms. Except for $P$. atlantica (NCMB3or) the nutritional spectra and mol \% GC of strains in phenon C were very similar to those described for Alteromonas marinopraesens Baumann et al. 1972, which has been renamed A. haloplanktis Reichelt \& Baumann 1973. This species includes strain NCMBI9 (MacLeod's BI6). We would therefore identify all strains of phenon $\mathrm{C}$, except NCMB3OI, as $A$. haloplanktis. Pseudomonas atlantica NCMB3OI just qualifies for phenon $\mathrm{C}$. In its nutritional spectrum it resembled $A$. macleodii but it could also liquefy agar, a property not possessed by any alteromonad described by Baumann et al. (1972). As we did not have the strains of $A$. macleodii for comparison we identify this strain just as an alteromonad.

Phenon $D$. This small phenon contains strains intermediate to those in phenons $\mathrm{C}$ and $\mathrm{E}$. All strains required $\mathrm{Na}^{+}$for growth but at lower levels than the strains in phenon $\mathrm{C}$ with an optimum at 0.2 to $0.3 \mathrm{M}-\mathrm{Na}^{+}$(Fig. $2 b$ ). They do not correspond to any previously described species but are probably alteromonads. There are too few strains to justify designation of a new species.

Phenon $E$ (including ss65). This phenon contains the strains previously identified as $P$. putrefaciens including NCIB I047 I and I0472, two of the original strains of Derby \& Hammer (I93I) and $P$. rubescens NCIB8768 (Pivnick, 1955) isolated from cutting oils. Only NCIBI I I 57 


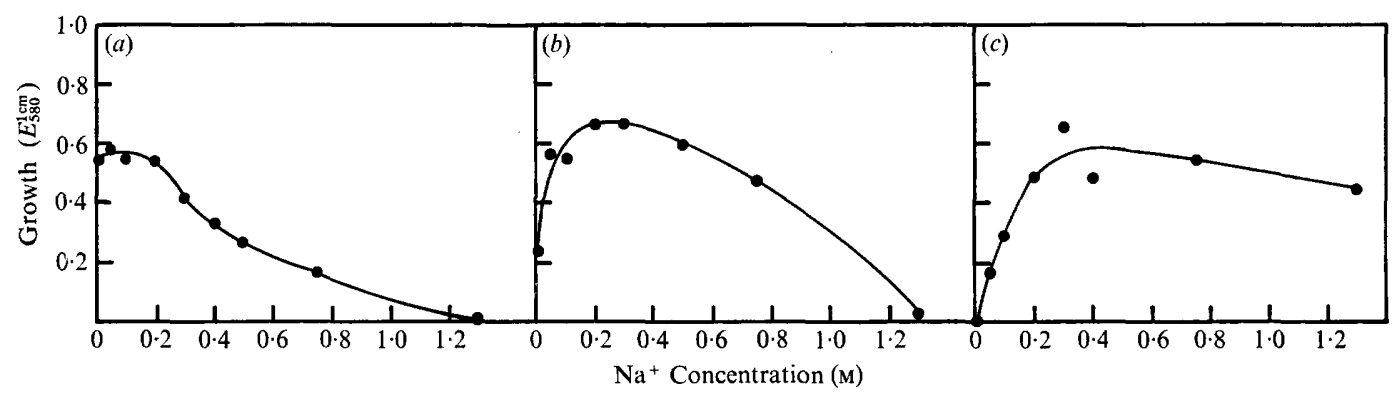

Fig. 2. Effect of $\mathrm{Na}^{+}$on growth. Twenty four strains were tested as described in Methods. (a) Response of NCMBI354 (phenon A). Similar results were obtained with NCMBI 29, 320 and 406, of phenon A, NCMBI733 and I735, NCIB8768 and III57, ss65 and I9I of phenon E, and NCMB335. (b) Response of NCMBI52I (phenon D). Similar results were obtained with the other two strains of phenon D. (c) Response of NCMBI 789 (phenon C). Similar results were obtained with NCMBI9, 224, 399, I5I6, I73I and I788 of phenon C, NCMB398 of phenon B, and NCMBI30 and I790.

and NCMBI 733 required $\mathrm{Na}^{+}$for growth but both could grow optimally in the presence of $0.005 \mathrm{M}^{-} \mathrm{Na}^{+}$(Fig. 2a). All except NCIBI I 56 and NCIBIII57 possessed ornithine decarboxylase, a property not found in any other strain studied. This test has been suggested as being useful for the identification of $P$. putrefaciens (Hugh, I970).

All the low mol \% GC strains examined appear to be inter-related. Phenon D and NCMBI30, 335 and 1790 are intermediate to the two major phenons $\mathrm{C}$ and $\mathrm{E}$. The clusters differ too little in properties to warrant being placed in separate genera. The strains of phenon $\mathrm{C}$ (excluding NCMB3OI) are identifiable as $A$. haloplanktis. Recently, single strains of the species $A$. communis, $A$. vaga, $A$. macleodii and $A$. haloplanktis when grown on glucose have been shown to have the characteristic enzymes of the Entner-Doudoroff pathway and no detectable phosphofructokinase (Baumann \& Baumann, 1973). These data are similar to the results reported here except that two, NCMB400 and 1790 , had only 2-keto-3-deoxy-6phosphogluconate aldolase.

According to Baumann et al. (1972) the genera Pseudomonas and Alteromonas are differentiated solely on the basis of mol \% GC. They stated that strains of the genus Alteromonas had a mol \% GC of 43 to 48 but they included organisms of $4 \mathrm{I} \cdot 8$ to $49 \cdot 0$. All the low mol \% GC strains studied here fell within the latter range except NCMB335 (5I.0\%), NCIBIO76I $\left(54^{\circ} \mathrm{I} \%\right.$ ) and NCIBI I I $57(54.7 \%)$. Strains NCIBI 076 I and I I I 57 fell in phenon E and NCMB335 was also closely related to phenon E strains. Accordingly, these three strains are sufficiently related to the other low mol \% GC strains to be included in the same genus. Therefore, all the non-fermentative strains with $\mathrm{mol} \% \mathrm{GC}$ of 55 or less are placed in the genus Alteromonas of Baumann et al. (1972).

Levin (1972) has suggested that $P$. putrefaciens strains could be divided into two groups on the basis of mol \% GC and the ability to grow in the presence of $6 \% \mathrm{NaCl}$. Although phenon $\mathrm{E}$ includes two subclusters which differ slightly in their mol \% GC, there are no distinctive differences between these two groups. All the strains of phenon $\mathrm{E}$ have been examined for their ability to grow in the presence of $6 \% \mathrm{NaCl}$ and they could not be divided as described by Levin. Therefore, although the phenon has a wider range $(44.7 \text { to } 54 \cdot 7)^{\circ}$ of mol \% GC than would generally be accepted for a single species, there is insufficient evidence at present to divide it into separate species or biotypes. It does not correspond to any species of alteromonad described by Baumann et al. (1972) but includes strains of $P$. putrefaciens and $P$. rubescens which are considered synonymous by Hugh (1970) as is corroborated by 
Table 6. Proposed identification scheme for Gram-negative, polarly flagellated, catalase and oxidase positive, non-fermentative bacteria

\begin{tabular}{|c|c|c|c|c|c|}
\hline \multirow{2}{*}{ Test } & \multicolumn{2}{|c|}{ Pseudomonads } & \multicolumn{3}{|c|}{ Alteromonads } \\
\hline & A & B & $\mathrm{C}$ & $\mathrm{D}$ & $\mathrm{E}$ \\
\hline $\begin{array}{l}\text { Glucose metabolism (Hugh \& } \\
\text { Leifson, 1953) }\end{array}$ & O & N/A & N/A & N/A & N/A \\
\hline TMAO reduction & - & - & - & + & + \\
\hline Requirement for $\mathrm{Na}^{+}$ & - & - & + & + & - \\
\hline DNAase & - & - & + & + & + \\
\hline Arginine dihydrolase & + & - & - & - & - \\
\hline Ornithine decarboxylase & - & - & - & - & + \\
\hline Sensitivity to penicillin (I.5 i.u.) & - & - & - & + & - \\
\hline
\end{tabular}

O, Oxidative; N/A, no change or alkaline; - , property absent in all strains; + , property present in all strains.

our results. We therefore propose that $P$. putrefaciens Derby \& Hammer I93 I and $P$. rubescens Pivnick 1955 be considered synonyms of Alteromonas putrefaciens Derby \& Hammer comb. nov. (phenon E). The strain NCIBIO47I is designated as the type strain of this species.

The results of the work described here and the inclusion of $A$. putrefaciens in the genus would require that the description of the genus Alteromonas include the following modified statements. The mol \% GC content of the DNA ranges from 43 to 55. They are strict aerobes except for those species which can use denitrification as a means of anaerobic respiration. Nearly all strains are capable of growth on a minimal medium containing artificial sea water with D-glucose as the sole source of carbon and energy, and ammonia as the sole source of nitrogen. Sodium ions but no organic growth factors may be required for growth. Some species may produce an extracellular DNAase. Some strains can hydrolyse agar.

The tests used in the analysis and some of the more commonly used bacteriological tests most useful in separating the phenons are shown in Table 6. The latter were easier to perform than some of the tests used to establish the groups. It is suggested that the tests (Table 6) could be useful in identifying $A$. putrefaciens and for dividing new isolates into the other phenons described here. Our results suggest that the strains of phenon $\mathrm{C}$ and $\mathrm{Na}^{+}$-requiring pseudomonads may prove difficult to distinguish. The only high mol $\% \mathrm{GC}, \mathrm{Na}^{+}$-requiring strain studied was NCMB398 which differed from phenon $\mathrm{C}$ strains solely in the absence of DNAase. Unfortunately, no other high mol \% GC Na${ }^{+}$-requiring strains were available for study. Obviously a much larger number of strains including more $\mathrm{Na}^{+}$-requiring pseudomonads needs to be studied to evaluate the usefulness of the proposed identification scheme. However, the Gram-negative, non-fermentative, oxidase positive and polarly flagellated organisms corresponding to Pseudomonas groups III and IV of Shewan et al. (1960) and of different mol \% GC content can now be clearly subdivided on characters other than mol $\%$ GC alone.

J. V. Lee acknowledges a Natural Environment Research Council grant. We would also like to thank H. R. Sanders and G. L. Smith for carrying out the computer analysis. 


\section{REFERENCES}

BAGGe, J. \& BAGGE, O. (1956). Vibrio anguillarum as the cause of ulcerous disease in codfish. Nordisk Veterinaermedicin 8, 48I-492.

Barnes, E. M. \& Melton, W. (I971). Extracellular enzymic activity of poultry spoilage bacteria. Journal of Applied Bacteriology 34, 599-609.

BaumanN, L. \& Baumann, P. (1973). Enzymes of glucose catabolism in cell-free extracts of non-fermentative marine bacteria. Canadian Journal of Microbiology 19, 302-304.

Baumann, L., Baumann, P., Mandell, M. \& Allen, R. D. (I972). Taxonomy of aerobic marine eubacteria. Journal of Bacteriology I10, 402-409.

Castell, C. H. \& Greenough, M. F. (I959). The action of Pseudomonas on fish muscle: 4 . Relation between substrate composition and the development of odours by Pseudomonas fragi. Journal of the Fisheries Research Board of Canada 16, 21-3I.

Clowes, R. C. \& HAYES, W. (1968). Experiments in Microbial Genetics. Oxford and Edinburgh: Blackwell Scientific Publications.

De Ley, J., Kersters, K., Khan-Matsubara, J. \& Shewan, J. M. (I970). Comparative D-gluconate metabolism and DNA base composition in Achromobacter and Alcaligenes. Antonie van Leeuwenhoek 36, 193-207.

DEN Dooren DE Jong, L. E. (1926). Bijdrage tot de kennis van het mineralisatieproces. Rotterdam: Nijgh and Van Ditmar.

DeRbY, H. A. \& HAMmer, B. W. (I93I). Bacteriology of butter. IV. Bacteriological studies on surface taint butter. Iowa Agricultural Experimental Station Research Bulletin 145, 389-416.

Graevenitz, A. von \& Simon, G. (1970). Potentially pathogenic, non-fermentative, $\mathrm{H}_{2}$ S-producing Gramnegative rod (I b). Applied Microbiology r9, 176.

Herbert, R. A., Hendrie, M. S., Gibson, D. M. \& Shewan, J. M. (1971). Bacteria active in the spoilage of certain seafoods. Journal of Applied Bacteriology 34, 4I-50.

HuGH, R. (1970). A practical approach to the identification of certain non-fermentative Gram-negative rods encountered in clinical specimens. Public Health Laboratory 28, 168-187.

Hugh, R. \& LeIFSON, E. (I953). The taxonomic significance of fermentative versus oxidative metabolism of carbohydrates by various Gram-negative bacteria. Journal of Bacteriology 66, 24-26.

Hugh, R. \& Ryschenkow, E. (I96I). Pseudomonas maltophilia, an Alcaligenes-like species. Journal of General Microbiology 26, I $23-132$.

JefFries, C. D., Holtman, D. F. \& Guse, D. G. (I957). Rapid method for determining the activity of microorganisms on nucleic acids. Journal of Bacteriology 73, 590-591.

Jonsson, V. (1970). Proposal of a new species Pseudomonas kingii. International Journal of Systematic Bacteriology 20, 255-257.

Kersters, K. (1967). Rapid screening assays for soluble and particulate bacterial dehydrogenases. Antonie van Leeuwenhoek 33, 63-72.

KERSTERS, K. \& De LEY, J. (I 968). An easy screening assay for the enzymes of the Entner-Doudoroff pathway. Antonie van Leeuwenhoek 34, 388-392.

LAYCOCK, R. H. \& REGIER, L. W. (I97I). Trimethylamine-producing bacteria on haddock (Melanogrammus aeglefinus) fillets during refrigerated storage. Journal of the Fisheries Research Board of Canada 28, 305-309.

LEE, J. V. (I973). Some comparative biochemical and physiological studies on selected Gram-negative bacteria. Ph.D. thesis, University of Aberdeen.

LEE, J. V., Grbson, D. M. \& ShEwAN, J. M. (1973). Comparative biochemical analysis of some pseudomonads. Journal of General Microbiology 77, xii.

LeIfson, E. (1970). Motile marine bacteria. IV. Ionic relationships of marine and terrestrial bacteria. Zentralblatt für Bakteriologie, Parasitenkunde, Infektionskrankheiten und Hygiene (Abteilung II) 125, I70-206.

LEvin, R. E. (1968). Detection and incidence of specific species of spoilage bacteria on fish. I. Methodology. Applied Microbiology 16, 1734-1737.

LeVIN, R. E. (1972). Correlation of DNA base composition and metabolism of Pseudomonas putrefaciens isolates from food, human clinical specimens, and other sources. Antonie van Leeuwenhoek 38, I 2 I-1 27.

MaCLeOd, R. A., ONOFreY, E. \& Norris, M. E. (1954). Nutrition and metabolism of marine bacteria: I. Survey of nutritional requirements. Journal of Bacteriology 68, 680-686.

Marcus, P. I. \& Talalay, P. (1956). Induction and purification of $\alpha$ - and $\beta$-hydroxy-steroid dehydrogenases. Journal of Biological Chemistry 218, 66I-674.

Minigawa, M. (1963). Studies on the strains closely related to Vibrio parahaemolyticus and reddish brown pigment-producing Pseudomonas isolated from the stools of patients of acute enteritis. Annual Report of the Institute of Food Microbiology, Chiba r6, 9-23.

MølleR, V. (1955). Simplified tests for some amino acid decarboxylases and for the arginine dihydrolase system. Acta pathologica et microbiologica scandinavica 36, I58-172. 
Murray, C. K. \& GiBson, D. M. (1972). An investigation of the method of determining trimethylamine in fish muscle extracts by the formation of its picrate salt: part I. Journal of Food Technology 7, 35-46.

Palleroni, N. J. \& Doudoroff, M. (1972). Some properties and subdivisions of the genus Pseudomonas. Annual Review of Phytopathology 10, 73-I00.

Pivnick, H. (1955). Pseudomonas rubescens, a new species from soluble oil emulsions. Journal of Bacteriology 7o, $\mathrm{I}-6$.

Reichelt, J. L. \& BaUmanN, P. (1973). Change of the name Alteromonas marinopraesens (ZoBell and Upham) Baumann et al. to Alteromonas haloplanktis (ZoBell and Upham) comb. nov. and assignment of strain ATCC2382I (Pseudomonas enalia) and strain C-AI of De Voe and Oginsky to this species. International Journal of Systematic Bacteriology 23, 438-44I.

Riley, P.S., Tatum, H.W. \& Weaver, R. E. (1972). Pseudomonas putrefaciens isolates from clinical specimens. Applied Microbiology 24, 798-800.

SHEwAN, J. M. (1974). The biodeterioration of certain proteinaceous foodstuffs at chill temperatures. In Industrial Aspects of Biochemistry. Edited by B. Spencer. London: North-Holland Publishing Company.

ShewAN, J. M., HobBS, G. \& HodgKISs, W. (1960). A determinative scheme for the identification of certain genera of Gram-negative bacteria with special reference to the Pseudomonadaceae. Journal of Applied Bacteriology 23, 379-390.

Sokal, R. R. \& SNeath, P. H. A. (1963). Principles of Numerical Taxonomy. San Francisco and London: W. H. Freeman.

Sols, A. \& Salas, M. L. (1966). Phosphofructokinase. Methods in Enzymology, 9, 436-442.

SørENSEN, T. (1948). A method of establishing groups of equal amplitude in plant sociology based on similarity of species content and its application to analyses of the vegetation of Danish commons. Biologiske Skrifter 5, I-34.

Stanier, R. Y., Palleroni, N. J. \& Doudoroff, M. (1966). The aerobic pseudomonads: a taxonomic study. Journal of General Microbiology 43, I59-27I.

ThorNLEY, M. J. (1960). The differentiation of Pseudomonas from other Gram-negative bacteria on the basis of arginine metabolism. Journal of Applied Bacteriology 23, 37-52.

YAPHE, W. (1957). The use of agarase from Pseudomonas atlantica in the identification of agar in marine algae (Rhodophyceae). Canadian Journal of Microbiology 3, 987-993. 